\title{
15-49 Yaş Aralığındaki Kadınlarda Bel Ağrısı Sıklığı, Etkileyen Faktörler ve Bel Ağrısının Fiziksel Aktivite Düzeyi ile İlişkisinin Belirlenmesi
}

\section{Determination of the Frequency of Low Back Pain, Affecting Factors and the Relationship Between Low Back Pain and Physical Activity Level in Women aged 15-49}

\author{
${ }^{1}$ Ceren BAYBAȘin, ${ }^{1}$ Günay SAKA \\ ${ }^{1}$ Dicle Üniversitesi, Tıp Fakültesi, Halk Sağlığı Anabilim Dalı, Diyarbakır, Türkiye \\ Günay Saka: https://orcid.org/0000-0001-9478-5491 \\ Ceren Baybaşin: https://orcid.org/ 0000-0001-9568-8095
}

\begin{abstract}
ÖZ
Amaç: $\mathrm{Bu}$ araştırma, Diyarbakır 16 nolu Aile Sağlı̆̆ Merkezi (ASM) bölgesinde yaşayan 15-49 yaş aralığındaki kadınlarda yaşam boyu, son bir yıl içindeki ve son üç ay içindeki bel ağrısı prevalanslarını tespit etmek amacıyla yapılmıştır.

Materyal ve Metot: Araştırmanın evrenini, Diyarbakır 16 nolu ASM bölgesinde yaşayan 4800 kadın, örneklemini ise sistematik örnekleme yöntemi ile seçilip ulaşılabilen 392 kadın oluşturmaktadır. Bel ağrısının, kadınların yaşam kalitesini ne kadar etkilediğini belirleyebilmek için Oswestry Özürlülük İndeksi, fiziksel aktivite düzeyini belirlemek için ise Uluslararası Fiziksel Aktivite Anketi uygulanmıştır. Verilerin analizi, SPSS 22 (Statistical Package for the Social Sciences 22,0) programı ile yapılmıştır. Bulgular: Elde edilen bulgulara göre, yaşam boyu bel ağrıs1 sıklığ1 \%70,4 olarak bulunmuştur. Kadınların Oswestry Özürlülük İndeksi puan ortalaması 12,5 $\pm 6,4$ bulunmuştur. Katılımcıların \%56,9'u minimum aktif, \% 33,9 'u ise inaktif çıkmıştır. İnaktif kadınlarda bel ağrıs1 sıklı̆̆ $1 \% 94$ bulunurken, çok aktif kadınlarda \%38,9 olarak bulunmuştur. Fiziksel aktivite düzeyi arttıkça bel ağrıs1 görülme sıklığı azalmaktadır.

Sonuç: Bel ağrısı ile ilgili olduğunu düşündüğümüz risk faktörlerinden medeni durum, yaş, vücut kitle indeksi, gebelik sayıs1, egzersiz yapma durumu, ev işleri yapma durumu ile bel ağrısı sıklığı arasında anlamlı ilişkiler bulunmuştur. $\mathrm{Bu}$ bilgiler 1şı̆̆ında, risk faktörlerine yönelik gerekli önlemler alındığı takdirde kadınlarda bel ağrısı sıklığı azaltılabileceği sonucuna ulaşılmıştır.

Anahtar Kelimeler: Bel ağrısı, fiziksel aktivite, kadın
\end{abstract}

\begin{abstract}
Objective: This study aims to determine the low back pain prevalence in three months, six months and lifelong period for the women which are in 15-49 age range and live in No.16 Family Health Center (FHC) area in Diyarbakir.
\end{abstract}

Materials and Methods: Study population is the 4800 women which live in Diyarbakir No.16 ASM Area and sample is 392 women which are chosen with systematic investigation method. To determine the low back pain which affect the life quality of women Oswestry Disability Index method and to determine the physical activity level, The International Physical Activity Questionnaire method is used. Data analysis has been made by SPSS 22 (Statistical Package for the Social Sciences 22.0) software. Results: According to result of findings the low back pain frequency is obtained as $70.4 \%$. The average Oswestry score of woman is found $12.5 \pm 6.4$. The results show that $56.9 \%$ of participants were active and $33.9 \%$ were inactive. The frequency of low back pain in inactive women is found $94 \%$ and also frequency of low back pain in active women is found as $38.9 \%$.

Conclusion: Results show that the risk factors such as marital status, age, BMI, gestation number, physical activity level, house works have significant relation with low back pain frequency. In the light of this information, we obtained that, taking due precautions about risk factors reduces the low back pain frequency in women.

Keywords: Low back pain, physical activity, woman

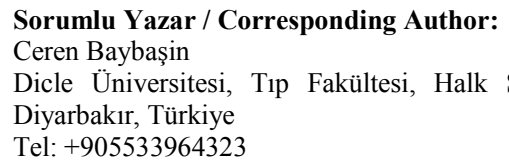




\section{GÍRIŞ}

Bel ağrısı, bütün etnik gruplarda rastlanan, birçok kişiyi etkileyen ve ülke ekonomisini olumsuz yönde etkileyen bir kas iskelet sistemi problemidir. Ayrıca, toplumda sık görülen, bireylerde iş gücü kaybına sebep olan ve tedavi maliyeti yüksek olan hastalıklardan biridir. Gelişmiş ülkelerde yapılan çalışmalara bakıldığında yaşam boyu bel ağrısı prevalansının \%59-80 arasında değiştiği görülmektedir. ${ }^{1,2}$ Kırsal bir bölgede, ev kadınlarında yapılan çalışmada bel ağrısının nokta prevalansı \%34,9 yaşam boyu bel ağrısı prevalansı ise \%79,2 bulunmuştur. ${ }^{3}$

Fiziksel aktivite Dünya Sağlık Örgütü tarafından iskelet kaslarının kasılmasıyla ortaya çıkan herhangi vücut hareketi olarak tanımlanmıştır. Düzenli ve yeterli miktarda fiziksel aktivitenin vücut kompozisyonu, kassal ve kardiyo-respiratuvar uygunluk, fonksiyonel sağlık ve psikolojik iyilik halinin gelişmesi; hipertansiyon, felç, diyabet, koroner kalp hastalığı, göğüs ve kolon kanseri riskinin azaltılması ve yaşam kalitesinin iyileştirilmesi gibi fiziksel fonksiyon ve psikolojik parametreler üzerinde olumlu etkisi vardır. ${ }^{4}$ İleri yaşla birlikte obezite ve fizik aktivite eksikliği bir yaşam biçimine dönüşür ve bu durum bel ağrısı prevalansını arttırmaktadır. ${ }^{2}$

Bel ağrılarında sınıflandırma, ağrının süresine, köken aldığı anatomik yapılara, mekanik veya enflamatuar karakterde olmasına vb. bağlı olarak çok farklı şekillerde yapılabilmektedir. ${ }^{5}$ Bel ağrılarının \%85'inin etiyolojisini belirlemek mümkün olmadığ1 için bu tür bel ağrılarına mekanik kökenli bel ağrısı denir. ${ }^{6}$ Mekanik Bel Ağrısı (MBA) omurgayı oluşturan yapılarda görülen fonksiyonel bozukluk sonucu ortaya çıkan bir tablodur ve birçok nedene bağlı olarak ortaya çıkabilir.

Esen ve ark. yaptığı bir çalışmada kadın cinsiyet bel ağrısı için bir risk faktörü olarak belirlenmiştir ve bu durumun kadınların fiziksel, hormonal yapılarının erkeklerden farklı olmasından kaynaklandığı bildirilmiştir. ${ }^{7}$ Birinci basamak sağlık kuruluşlarına başvuranlarda bel ağrısı sıklığının araştırıldığı başka bir çalışmada, yaşam boyu bel ağrısı (YBBA) riski kadınlarda erkeklere göre 1.82 kat daha fazla bulunmuştur. ${ }^{8}$

Çalışmamızın amacı, 15-49 yaş aralığındaki kadınlarda YBBA sıklığını tespit etmek, bel ağrısına yol açan etmenleri daha iyi tanımlamak ve bel ağrısının fiziksel aktivite ile ilişkisini incelemektir.

\section{MATERYAL VE METOT}

$\mathrm{Bu}$ araştırma Dicle Üniversitesi Tıp Fakültesi Giri- şimsel Olmayan Klinik Araştırmalar Etik Kurulu tarafından onaylanmıştır (Tarih: 25.12.2015, karar no: 111). Katılımcılar çalışma hakkında bilgilendirilmiş ve onamları alınan kişiler çalışmaya dahil edilmiştir. Çalışma Uluslararası bildirgeler dikkate alınarak yapılmıştır.

Çalışmanın evreni, Diyarbakır Kayapınar 16 nolu Aile Sağlığı Merkezi (ASM) bölgesinde yaşayan 15 49 yaş aralığındaki 4800 kadından oluşmaktadır. Örneklem hacmi, Epi İnfo 7 istatistik programında $\mathrm{P}=0,50, \% 95$ güven aralığında ve beklenen frekans \%35 belirlenerek örneklem hacmi 326 bulunmuştur. $^{3}$ Sistematik örnekleme yöntemi kullanılarak 400 kişiye ulaşmak hedeflenmiştir.

Kayapınar 16 nolu ASM' den 15-49 yaş aralığındaki kadınların listesi alınmış ve 4800 kişilik liste 12 kişilik 400 bölüme ayrılmıştır ve her bölümden bir asil iki yedek seçilmiştir. Gebelik araştırmaya dâhil edilmeme kriterlerinden sayılmıştır.

Araştırmada kullanılan anket formu, literatür taraması ve yapılan gözlemler eşliğinde oluşturulmuştur. Anket soruları, demografik bilgiler, ev işleri ve egzersiz yapma durumları, bel ağrısı varlığı, ailede bel ağrısı varlığı, bel ağrısıyla ilgili alınan tedaviler, Oswestry Özürlülük İndeksi (OÖİ) ve Uluslararası Fiziksel Aktivite Anketinden (UFAA) oluşmaktadır. “'Oswestry Özürlülük İndeksi (OÖİ)'nin Türkiye'de geçerlilik ve güvenilirlik çalışması Yakut ve arkadaşları tarafından 2004 yılında yapılmıştır. ${ }^{9}$ Başlangıçta, her grup kendi içinde puanlandırılmıştır. $\mathrm{Bu}$ puanlamaya göre her gruptan alınabilecek en düşük puan sıfır, en yüksek puan 5'tir. Her kategorinin ayrı puanlanmasının ardından, tüm kategori puanları toplanıp ve toplam puan elde edilmiştir.

Uluslararası Fiziksel Aktivite Anketi (FADA); kişilerin günlük hayatlarının bir parçası olarak yaptıkları fiziksel aktivite çeşitleri değerlendirilerek puanlama yapılmaktadır. Sorular son 7 gün içerisinde fiziksel olarak harcanan zamanla ilgilidir. Anket; yürüme, orta-şiddetli ve şiddetli aktivitelerde harcanan zaman hakkında bilgi sağlamaktadır. Oturmada harcanan zaman ayrı bir soru olarak değerlendirilmektedir. Kısa formun toplam skorunun hesaplanması yürüme, orta şiddetli aktivite ve şiddetli aktivitenin süre (dakikalar) ve sıklık (günler) toplamlarından elde edilmektedir. $^{10}$

Anketin bel ağrısıyla ilgili kısmında YBBA (Yaşam Boyu Bel Ağrısı), son 1 yıldaki bel ağrısı prevalansı (yearly low back pain prevalance) ve son üç ay içerisinde fiziksel aktivite ile artan bel ağrısı prevalansını saptamaya yönelik sorular sorguland. 
Verilerin Analizi: Araştırma verileri SPSS (Statistical Package for Social Sciences ) 22,0 paket programı ile analiz edilmiştir. Ölçümsel değişkenler ortalama \pm standart sapma ile kategorik değişkenler ise sayı ve yüzde ile ifade edilmiştir. Verilerin analizinde, ikili kategorik değişkenler arasındaki ilişkiye bakmak için ki-kare analizi yapılmıştır. Tüm istatistiksel analizler için anlamlılık düzeyi $(p<0,05)$ olarak alınmıştır.

\section{BULGULAR}

Araştırmaya 15- 49 yaşları arasında 392 kadın katıl-

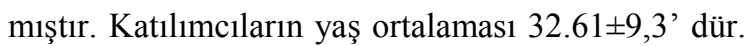
Katılımcıların, \%26,0'sı 15-25 yaş aralığında, \% 32,9'u 26-35 yaş aralığında,\%41,1'i de 36-49 yaş aralığındadır. Kadınların \%62 (n=243)'si evli ,\%38 (149) bekârdır. Katılımcıların \%71,2 (n=279)' si ev hanımı, \%16,6 (64)'sı çalışan, \%12,2 (49)'si ise öğrencidir (Tablo 1)

Tablo 1. Diyarbakır 16 nolu ASM bölgesinde yaşayan 15-49 yaş aralığındaki kadınların sosyodemografik özellikleri.

\begin{tabular}{|c|c|c|c|}
\hline & & $\mathbf{N}$ & $\mathbf{\%}$ \\
\hline \multirow{4}{*}{ Yaş } & $15-25$ yaş & 102 & 26,0 \\
\cline { 2 - 4 } & $26-35$ yaş & 129 & 32,9 \\
\cline { 2 - 4 } & $36-49$ yaş & 161 & 41,1 \\
\hline \multirow{4}{*}{ Medeni durum } & Evli & 243 & 62,0 \\
\cline { 2 - 4 } & Bekâr & 149 & 38,0 \\
\hline \multirow{4}{*}{ Eğitim durumu } & Okur-yazar & 28 & 6,9 \\
\cline { 2 - 4 } & İlkokul & 53 & 13,5 \\
\cline { 2 - 4 } & Ortaokul & 108 & 27,6 \\
\cline { 2 - 4 } & Linise & 162 & 41,3 \\
\hline Toplam & & 41 & 10,7 \\
\hline
\end{tabular}

Katılımcıların genel sağlık durumlarına ilişsin veriler Tablo 2 de gösterilmiştir. Kadınların kilo ortalamaları 64,7 $\pm 11,4$ 'tür. Kadınların \%44,1 (n=173) i normal kilolu \%39,8 (n=156)'i ise fazla kiloludur. Kadınların \%68,1 (n=267)'i hayatları boyunca hiç sigara içmemişlerdir (Tablo 2).

Kadınların \%6,1 (n=24)'i her gün düzenli, \%28,6 (112)'ü ise ara sira egzersiz yapmaktadır. $256(\%$ $65,3)$ kadın ise egzersiz yapmamaktadır. Fiziksel aktivite anketi skorlarına göre kadınların \%33,9 (133) inaktif, \%56,9 (223)'u minimum aktif, \%9,2 (36)'sı ise çok aktiftir. Fiziksel aktivite skorları hesaplanırken günlük yürüme ve oturma sürelerine karşılık gelen MET değerleri hesaplandığı için egzersiz yapmayan kadınların bir kısmı inaktif olarak bulunmamıştır. Kadınların \%59,2 (232)’si her gün ev işleri yapmaktadır. Kadınların \%40,1 inin hiç gebelik öyküsü yok iken \%44,9 (n=176)'u iki ve üzeri gebelik yaşamıştır. Katılımcıların \%31,1 (122)'inin ailesinde bel ağrısı öyküsü bulunurken \% 68,9 (270)'unun aile öyküsü bulunmamaktadır (Tablo 2).

Tablo 2. Diyarbakır 16 nolu ASM bölgesinde yaşayan 15-49 yaş aralığındaki kadınların genel sağlık durumlarına ilişkin bilgiler.

\begin{tabular}{|c|c|c|c|}
\hline & & $\mathbf{N}$ & $\%$ \\
\hline \multirow{4}{*}{$\begin{array}{l}\text { Beden kitle in- } \\
\text { deksi }\end{array}$} & Düşük kilolu( <18,5) & 17 & 4,3 \\
\hline & Normal(18,5 -24,9) & 173 & 44,1 \\
\hline & Fazla kilolu(25-29,9) & 156 & 39,8 \\
\hline & Obez $(<30)$ & 46 & 11,7 \\
\hline \multirow{2}{*}{$\begin{array}{l}\text { Yaşam boyu } \\
\text { sigara içme duru- } \\
\text { mu }\end{array}$} & Evet & 125 & 31,9 \\
\hline & Hayır & 267 & 68,1 \\
\hline \multirow{3}{*}{$\begin{array}{l}\text { Egzersiz yapma } \\
\text { durumu }\end{array}$} & Düzenli, her gün & 24 & 6,1 \\
\hline & Ara sira & 112 & 28,6 \\
\hline & Egzersiz yapmam & 256 & 65,3 \\
\hline \multirow{2}{*}{$\begin{array}{l}\text { Her gün, düzenli } \\
\text { ev işleri yapma } \\
\text { durumu }\end{array}$} & Evet & 232 & 59,2 \\
\hline & Hayır & 160 & 40,8 \\
\hline \multirow[b]{3}{*}{ Gebelik sayıları } & 0 & 157 & 40,1 \\
\hline & 1 & 59 & 15,1 \\
\hline & 2 ve üzeri & 176 & 44,9 \\
\hline \multirow{2}{*}{$\begin{array}{l}\text { Ailede bel ağrısı } \\
\text { varlığı }\end{array}$} & Evet & 122 & 31,1 \\
\hline & Hayır & 270 & 68,9 \\
\hline \multirow{3}{*}{$\begin{array}{l}\text { Fiziksel Aktivite } \\
\text { Düzeyi }\end{array}$} & İnaktif & 133 & 33,9 \\
\hline & Minimum Aktif & 223 & 56,9 \\
\hline & Çok Aktif & 36 & 9,2 \\
\hline \multicolumn{2}{|l|}{ Toplam } & 392 & 100 \\
\hline
\end{tabular}

15- 49 yaş aralığındaki kadınların yaşam boyu bel ağrısı sıklığı \%70,4 olarak bulunmuştur. Son bir yıldaki bel ağrısı prevalansı \%34,2, son üç aydaki bel ağrısı prevalansı ise \%27,3 olarak saptanmıştır (Tablo 3).

Tablo 3. Bel ağrısı prevalans değerleri.

\begin{tabular}{|l|l|c|c|}
\hline & & $\mathbf{N}$ & $\mathbf{\%}$ \\
\hline \multirow{2}{*}{$\begin{array}{l}\text { Yaşam boyu bel ağrısı } \\
\text { prevalansı }\end{array}$} & Evet & 276 & 70,4 \\
\cline { 2 - 4 } & Hayır & 116 & 29,6 \\
\hline \multirow{2}{*}{$\begin{array}{l}\text { Son bir yıldaki bel ağrısı } \\
\text { prevalansı }\end{array}$} & Evet & 134 & 34,2 \\
\cline { 2 - 4 } & Hayır & 258 & 65,8 \\
\hline $\begin{array}{l}\text { Son üç ay içinde fiziksel } \\
\text { aktivite ile artan bel ağrısı }\end{array}$ & Evet & 107 & 27,3 \\
\cline { 2 - 4 } & Hayır & 285 & 72,7 \\
\hline Toplam & & $\mathbf{3 9 2}$ & $\mathbf{1 0 0}$ \\
\hline
\end{tabular}

Bel ağrısı olan kadınların, \%58,2'si ağrının şiddetini hafif \%17,2'si de şiddetli olarak tanımlamıştır. Son bir yılda bel ağrısı yaşayan kadınların \%45,5 
(61)'inin ağrısı 6 haftadan daha az sürmüştür, \%20,1 (27) 'lik kısmında ise kronik bel ağrısı mevcuttur. Bel ağrılı kadınların, \%63,4 (85)' ü bel ağrısına yönelik herhangi bir tetkik yaptırmamıştır. Son bir yıl içerisinde bel ağrısı yaşayan kadınların \%60,4 (81)‘ü, bel ağrısına neden olan sorunla ilgili tıbbi bir tanı almamıştır. Bel ağrısı olan kadınların \%56,0 (75)'sı bel ağrısıyla ilgili tedavi görmüştür, \%44,0 (59)'ü ise hiç tedavi görmemiştir (Tablo 4).

Tablo 4: Son Bir yılda bel ağrısı yaşayan kadınlarda bel ağrısının özellikleri, Oswestry Bel Ağrısı Anketi puanları bel ağrısıyla ilgili tetkik yaptırma ve tanı ve tedavi alma durumları.

\begin{tabular}{|c|c|c|c|}
\hline & & $\mathbf{N}$ & $\%$ \\
\hline \multirow{3}{*}{$\begin{array}{c}\text { Bel ağrisının } \\
\text { şiddeti }\end{array}$} & Hafif & 78 & 58,2 \\
\hline & Orta & 33 & 24,6 \\
\hline & Şiddetli & 23 & 17,2 \\
\hline \multirow{3}{*}{$\begin{array}{l}\text { Bel ağrısının } \\
\text { süresi }\end{array}$} & 6 haftadan az & 61 & 45,5 \\
\hline & 6 haftayla 3 ay aras 1 & 46 & 34,3 \\
\hline & 3 aydan fazladır & 27 & 20,1 \\
\hline \multirow{2}{*}{$\begin{array}{l}\text { Tetkik yaptır- } \\
\text { ma durumu }\end{array}$} & Evet & 49 & 36,6 \\
\hline & Hayır & 85 & 63,4 \\
\hline \multirow{2}{*}{\begin{tabular}{|c|} 
Bel ağrisıyla \\
ilgili tanı alma \\
durumu
\end{tabular}} & Evet & 53 & 39,6 \\
\hline & Hayır & 81 & 60,4 \\
\hline \multirow{2}{*}{$\begin{array}{c}\text { Bel ağrısıyla } \\
\text { ilgili tedavi } \\
\text { alma duru- } \\
\text { mu } \\
\end{array}$} & Evet & 75 & 56,0 \\
\hline & Hayır & 59 & 44,0 \\
\hline \multirow[t]{4}{*}{$\begin{array}{l}\text { Oswestry Bel } \\
\text { Ağrısı Anketi } \\
\text { Puanları }\end{array}$} & $\begin{array}{l}\text { Bel ağrısı hastanın } \\
\text { yaşamında önemli bir } \\
\text { problem oluşturmuyor. }\end{array}$ & 69 & 51,5 \\
\hline & $\begin{array}{l}\text { Bel ağrısı hastanın } \\
\text { yaşamını hafif de- } \\
\text { recede kısıtlıyor. }\end{array}$ & 51 & 38,1 \\
\hline & $\begin{array}{l}\text { Bel ağrısı hastanın } \\
\text { yaşamını ileri de- } \\
\text { recede kısıtlıyor. }\end{array}$ & 13 & 9,7 \\
\hline & $\begin{array}{l}\text { Bel ağrısı nedeniyle } \\
\text { hastanın yaşamı tama- } \\
\text { men kısıtlanmış. }\end{array}$ & 1 & 0,7 \\
\hline Toplam & & 134 & 100 \\
\hline
\end{tabular}

Son bir yılda bel ağrısı yaşayan kadınların oswestry skorları değerlendirildiği zaman, toplam puan ortalamas1 12,5 $\pm 6,4$ bulunmuştur. Oswestry bel ağrıs1 skorlarına göre katılımcıların , \%51,5 (69)'inin yaşamında önemli bir problem oluşturmuyor, $\% 38,1$ (51)'inin günlük yaşamını hafif derecede kısıtlıyor, $\% 9,7(13)$ 'sinin günlük yaşamını ileri derecede kısıtlıyor, \%0,7 (1)'sinin günlük yaşamını tamamen kı- sitliyor ya da hasta semptomları abartıyordur (Tablo 4).

Katılımcıların, yaşam boyu bel ağrısı prevalansı değerlerinin katılımcıların medeni durumlarına göre dağılımını incelediğimiz zaman, evli kadınların \% 81,9 (199)'unun, bekâr kadınların ise \%51,7 (77)'sinin yaşamlarının herhangi bir döneminde bel ağrısı yaşadığı tespit edilmiştir. Bekâr kadınların \% 48,3 (72)'ü hiç bel ağrısı yaşamamıştır. İstatistiksel analiz sonuçlarına göre aralarında anlamlı fark bulunmuştur $(\mathrm{p}<0,05)$, (Tablo 5).

Tablo 5. Diyarbakır 16 nolu ASM bölgesinde yaşayan 15-49 yaş aralığındaki kadınların bel ağrısıyla ilişkili risk faktörleri.

\begin{tabular}{|c|c|c|c|}
\hline Risk faktörleri & $\begin{array}{l}\text { Bel ağrısı olan } \\
\text { (n) }(\%)\end{array}$ & $\begin{array}{l}\text { Bel ağrısı } \\
\text { olmayan } \\
\text { (n) }(\%)\end{array}$ & p değeri \\
\hline \multicolumn{4}{|c|}{ Medeni durum } \\
\hline Evli & $199(\% 81,9)$ & $44(\% 18,1)$ & \multirow[t]{2}{*}{$\mathbf{P}<0,05$} \\
\hline Bekar & $77(\% 51,7)$ & $72(\% 48,3)$ & \\
\hline \multicolumn{4}{|c|}{ BMI } \\
\hline Düşük kilolu & $6(\% 35,3)$ & $11(\% 64,7)$ & \multirow{4}{*}{$\mathbf{P}<\mathbf{0 , 0 5}$} \\
\hline Normal kilolu & $102(\% 59,0)$ & $71(\% 41,0)$ & \\
\hline Fazla kilolu & $126(\% 80,8)$ & $30(\% 19,2)$ & \\
\hline Obez & $42(\% 91,3)$ & $4(\% 8,7)$ & \\
\hline \multicolumn{4}{|c|}{ Gebelik sayıları } \\
\hline $\mathbf{0}$ & $75(\% 47,8)$ & $82(\% 52,2)$ & \multirow{3}{*}{$\mathbf{P}<\mathbf{0 , 0 5}$} \\
\hline 1 & $43(\% 72,9)$ & $16(\% 27,1)$ & \\
\hline 2 ve üzeri & $158(\% 89,8)$ & $18(\% 10,2)$ & \\
\hline \multicolumn{4}{|c|}{ Egzersiz yapma durumu } \\
\hline Düzenli, her gün & $8(\% 33,3)$ & $16(\% 66,7)$ & \multirow{3}{*}{$\mathbf{P}<\mathbf{0 , 0 5}$} \\
\hline Ara sira & $75(\% 67,0)$ & $37(\% 33,0)$ & \\
\hline Egzersiz yapmam & $193(\% 75,4)$ & $63(\% 24,6)$ & \\
\hline \multicolumn{4}{|c|}{ Sigara içme durumu } \\
\hline $\begin{array}{l}\text { Her gün en az bir } \\
\text { tane içiyorum }\end{array}$ & $33(\% 75,0)$ & $11(\% 25,0)$ & \multirow{4}{*}{$P>0,05$} \\
\hline $\begin{array}{l}\text { Haftada en az bir } \\
\text { tane içiyorum }\end{array}$ & $22(\% 68,8)$ & $10(\% 31,3)$ & \\
\hline $\begin{array}{l}\text { Haftada bir } \\
\text { taneden daha az } \\
\text { içiyorum }\end{array}$ & $15(\% 71,4)$ & $6(\% 28,6)$ & \\
\hline İçmiyorum & $206(\% 69,8)$ & $89(\% 30,2)$ & \\
\hline \multicolumn{4}{|c|}{ Yaş aralığı } \\
\hline $15-25$ & $38(\% 37,3)$ & $64(\% 62,7)$ & \multirow{3}{*}{$\mathbf{P}<\mathbf{0 , 0 5}$} \\
\hline 26-35 & $93(\% 72,1)$ & $36(\% 27,9)$ & \\
\hline $36-49$ & $145(\% 90,1)$ & $16(\% 9,9)$ & \\
\hline \multicolumn{4}{|c|}{ Fiziksel aktivite düzeyi } \\
\hline İnaktif & $125(\% 94,0)$ & $8(\% 6,0)$ & \multirow{3}{*}{$\mathbf{P}<\mathbf{0 , 0 5}$} \\
\hline Minimum Aktif & $137(\% 61,4)$ & $86(\% 38,6)$ & \\
\hline Çok aktif & $14(\% 38,9)$ & $22(\% 61,1)$ & \\
\hline Toplam & 276 & 116 & \\
\hline
\end{tabular}

Kadınlarda, bel ağrısı ile BMI arasındaki ilişki incelendiği zaman, obez kadınların \%91,3 (42)'ünün, fazla kilolu kadınların \%80,8 (126)'inin, düşük kilo- 
lu kadınların ise \%35,3 (6)'ünün yaşamının herhangi bir anında bel ağrısı yaşadığı tespit edilmiştir. Düşük kilolu kadınların \%64,7 (11)'si hayatları boyunca hiç bel ağrısı şikâyetleri yaşamamıştır. Beden kitle indeksi ve yaşam boyu bel ağrısı sıklığı arasında istatistiksel olarak anlamlı fark bulunmuştur $(\mathrm{p}<0,05)$, (Tablo 5).

Düzenli, her gün egzersiz yapan kadınların \% 33,3'sinde bel ağrısı görülürken, egzersiz yapmayan kadınlarda bel ağrısı sıklığı \% 75,4 bulunmuştur. Aralarında $\mathrm{p}<0,05$ düzeyinde anlamlı fark bulunmuştur. Düzenli olarak her gün ev işleri yapan kadınların \%83,6 (194)'sı yaşamlarının herhangi bir döneminde bel ağrısı yaşamışlardır. Bel ağrısı olmayan 116 kadından 78 tanesi düzenli olarak her gün ev işleri yapmamaktadır. Her gün düzenli olarak ev işleri yapmayan kadınların ise \%51,2'si yaşamlarının herhangi bir anında bel ağrısı geçirmiştir $(p<0,05)$. Düzenli olarak her gün ev işleri yapan kadınlarda, bel ağrısı görülme riski yapmayanlara göre 4,9 kat daha fazladır (Tablo 5).

15-25 yaş aralığındaki kadınların \%37,3'ü, 26-35 yaş aralığındaki kadınların \%72,1'i, 36-45 yaş aralığındaki kadınların ise \%90,1'i yaşamının herhangi bir döneminde bel ağrısı yaşamıştır. 36-49 yaş aral1ğındaki kadınların \%9,9'u hayatları boyunca hiç bel ağrısı yaşamamışlardır. İstatistiksel analiz sonuçlarına göre, yaş grupları ile yaşam boyu bel ağrısı sıklığı arasındaki istatistiksel açıdan anlamlı fark bulunmuştur ( $\mathrm{p}<0,05)$, (Tablo 5).

Yaşam boyu bel ağrısı sıklığı ve fiziksel aktivite düzeyi arasındaki ilişkiyi saptamak amacıyla yapılan istatistiksel analiz sonuçlarına göre, katılımcıların yaşam boyu bel ağrısı prevalansı ile fiziksel aktivite düzeyi arasındaki ilişki istatistiksel olarak anlamlı bulunmuştur ( $\mathrm{p}<0,05)$, (Tablo 5).

\section{TARTIŞMA VE SONUÇ}

Yapılan bazı araştırmaların sonuçlarına göre, kadınlarda da erkeklerde de en sık görülen şikâyetin bel ağrısı olduğu saptanmıştır. Algoloji kliniğine başvuran hastaların değerlendirildiği bir çalışmada, kanser dışı ağrı (KDA) nedenleri arasında en sık bel ağrısı (\%30), ikinci sıklıkla nöropatik ağrı $(\% 16,7)$ ve üçüncü sıklıkla miyofasial ağrı $(\% 15,4)$ tespit edilmiştir. ${ }^{11}$ Bansal ve ark. yaptığ boyu bel ağrısı prevalansı \%65 bulunurken, son bir yılda bel ağrısı görülme sıklığı ise \%56 olarak bulunmuştur. ${ }^{12}$ Rusya'da yapılmış bir çalışmada ise bel ağrısı prevalansı kadın cinsiyeti, yüksek vücut kitle indeksi ve fiziksel inaktivite ile ilişsili bulunmuştur. ${ }^{13}$ Türkiye'de yapılan benzer bir çalışmada, ka- dınların \%67,3' ünün yaşamlarının bir döneminde bel ağrısı yaşadıkları bildirilmiştir. ${ }^{14}$ Manisa' da kırsal bir bölgedeki kadınlarda yapılan çalışmada, araştırma grubunda yaşam boyu bel ağrısı sıklığı \% 79,2 bulunmuştur.

Vücut Kitle İndeksi (VKİ), yaşam boyu bel ağrısı sıklığında istatistiksel olarak anlamlı bir değişkendir. Vindigni ve ark. yaptığı bir araştırmada araştırmamız1 destekler yönde, obezite ve bel ağrısı arasında anlamlı bir ilişki bulunmuştur. ${ }^{15}$ Fakat obezite ile bel ağrısı arasındaki ilişki tam olarak anlaşılamamıştır, intervertebral disklere direkt mekanik stres ve aterosklerozun lomber kan akımı üzerine indirekt etkileri sebebiyle diskleri olumsuz olarak etkileyerek bel ağrısına neden olduğu düşünülmektedir. ${ }^{16}$ Başka bir çalışmada ise, katılımcıların \%50.'sinde bel ağrısı hastanın yaşamında önemli bir problem oluşturmad1ğ1, \%31,2'sinde günlük yaşamını hafif derecede k1sitladığ1, \%13,2'sinde ileri derecede kısıtladığ 1 sonucuna ulaşılmıştır. ${ }^{17}$

Geriartrik bireylerle yapılan bir çalışmadan elde edilen verilere göre kadınların erkeklerden daha yüksek şiddette bel ağrısına sahip oldukları fakat aralarında anlamlı bir ilişki olmadığı sonucuna ulaşılmıştır. Bel ağrısı riskine göre sınıflandırılan kadın ve erkek bireylerin bel ağrısı şiddetleri ayrı ayrı değerlendirilmiş ve potansiyel risk grubunda erkek bireylerin, önemli risk grubunda ise kadın bireylerin anlamlı derecede yüksek ağrı şiddetine sahip oldukları görülmüştür. Bu farklılığın sebebi olarak da toplumda erkek ve kadın cinsiyetin çalışma ve yaşam şekillerinin farklılığına işaret etmişlerdir. ${ }^{18}$

Beija ve ark. yaptığ 1 bir çalışmada egzersiz ve düzenli spor yapmanın bel ağrısı sıklığını azalttığı ve önlediği sonucuna ulaşılmıştır. ${ }^{19}$ Yapılan başka bir çalışmada ise egzersiz yapma ve bel ağrısı arasındaki ilişki istatistiksel olarak anlamlı bulunmamıştır. ${ }^{20}$ Çalışmamızda ise egzersiz yapmayan kadınlarda yaşam boyu bel ağrısı sıklığı, düzenli her gün egzersiz yapan kadınlardan 2,2 kat daha fazla bulunarak literatürle benzerlik göstermektedir.

Araştırmamızda, her gün düzenli olarak ev işleri yapan kadınlarda yaşam boyu bel ağrısı görülme riski, ev işleri yapmayan kadınlardan 1,7 kat daha fazladır. Benzer bir çalışmada, ev işleri sırasında taşınan yükün ağırlığı, yaşam boyu prevalansında istatistiksel olarak anlamlı bir değişken olduğu belirtilmiştir. ${ }^{3}$ Başka bir araştırmada ise ev işleri yapmanın bel ağrısı görülme riskini 2,82 kat arttırdığı tespit edilmiştir. $^{12}$

Tavares ve ark. yaptı̆̆ı bir çalışmada doğumdan sonraki 1,3 ve 6 . aylarda kadınların \%15-21'inin bel 
ağrısı yaşadığı bildirilmiştir. ${ }^{21}$ Araştırmamızda gebelik sayısı 2 ve üzeri olan kadınlarda bel ağrısı prevalansı daha yüksek olarak bulunmuş ve gebelik sayısı ile bel ağrısı arasındaki ilişki istatistiksel olarak anlamlıdır.

Yapılan çalışmalarda, bel ağrısı olanlarda sağlık kuruluşuna başvurma oranı \%46,1, ilaç kullanma \% 90,8 , bir şey yapmama ise \%9,2 olarak bulunmuştur. ${ }^{22}$ Benzer başka çalışmalarda da ilaç kullanım oranının \%42,1-79 arasında değiştiği belirtilmiştir. ${ }^{23}$ Çalışmamızda ilaç kullanma oranı \%38,1 oranında ağrıyı azaltmak için en çok tercih edilen yöntem olarak bulunmuştur.

Literatürdeki bir çalışmada, bel ağrısı olan kadınların \%82,1'i (n=183) bel ağrısıyla ilgili tanı almadığ1nı, \%17,9'u (n=40) ise tanı aldığını belirtmiştir. Bel ağrısı sonucu tanı alanların \%67,5'i (n=27) bel fitı ${ }_{1}$ tanısı almıştır. ${ }^{24}$ Araştırmamızda, son bir yıl içerisinde bel ağrısı yaşayan kadınların \%60,4'ü bel ağrısında neden olan sorun ile ilgili tıbbi bir tanı almamıştir.

Çok uluslu bir araştırmanın sonucuna göre bel ağrısı ile evli veya boşanmış/hiç evlenmemiş olma arasındaki ilişki istatistiksel olarak anlamlı bulunmuştur. ${ }^{25}$ Çalışmamızdan elde edilen veriler eşliğinde, benzer şekilde evli kadınlarda bel ağrısı görülme riskinin daha fazla olduğuna dikkat çekebiliriz. Covid 19 pandemi sürecinde, karantinada kalan bireylerle yapılan bir çalışmada karantina öncesi bel ağrısı prevalans1 \%38,8 bulunurken karantina sonrası bu değerin \%43,8'e çıktığ1 görülmüştür. ${ }^{26} \mathrm{Bu}$ durum kişilerin karantina sürecinde ev içerinde hareketsiz kalmalarıyla ilişkilendirilmiştir. Araştırmamızın sonuçlarına göre de fiziksel aktivite düzeyi inaktif olarak bulunan kadınlarda bel ağrısı prevalansı \%94,0 aynı zamanda inaktif kadınlarda bel ağrısı görülme riski, çok aktif kadınlardan 2,4 kat daha fazla olarak bulunmuştur.

Wáng ve ark., 772,927 kadın ve erkeğin yaşa bağlı bel ağrısı prevalansılarını değerlendirdiği bir literatür incelemesinde, kadınların tüm yaş gruplarında daha yüksek bel ağrısı prevalansına sahip olduğunu bildirmiştir. Yapılan araştırmada bel ağrısı insidansının kadınlarda 65 yaş üzerinde keskin bir şekilde yükseldiği sonucuna ulaşılmıştır. Araştırmamızda da en yüksek bel ağrısı prevalansı 36-49 yaş aralığında bulunmuştur. $^{27}$

Araştırmamızda, katılımcıların Oswestry puanlarına göre bel ağrısının, \%50,8'inin hayatında önemli problem oluşturmadığı tespit edilmiştir. Literatürdeki bir çalışmada, Oswestry puan ortalaması, 25,32 $\pm 14,7$ bulunmuştur. ${ }^{22}$ Araştırmamızdaki kadın- ların genel olarak çok ağır işlerde çalışmadığını göz önde bulundurursak, araştırmamızın Oswestry puan ortalamasının benzer çalışmadan düşük çıkmasının sebebini açıklayabiliriz. Aynı çalışmada bel ağrısı, katılımcıların \%54,8'inin hayatında önemli bir problem oluşturmamaktadır diye belirtilmektedir.

Sonuç olarak, toplumuzda kadınlarında bel ağrısının bu kadar sık görülmesi, hem kadınların yaşam kalitesi üzerinde olumsuz etkiler birakır hem de istenmeyen sakatlıklara yol açabilir. İnaktif kadınlarda bel ağrısı görülme riski çok aktif kadınlara göre daha fazladır. Fiziksel aktivitenin bel ağrısı üzerinde olumlu etkisi göz önünde bulundurularak, 15-49 yaş aralığındaki kadınlar daha fazla fiziksel aktivite yapmaya teşvik edilmelidir. Bu yaş grubundaki kadınların bel ağrısı konusunda daha fazla bilinçlendirilmesi gerekmektedir. Bel ağrısı olan kadınlar hekime başvurma konusunda teşvik edilmelidir. Bel ağrısı çok sık tekrarlayan bir hastalık olması sebebiyle risk faktörlerini sahip olan tüm bireylere, özellikle de kadınlara bel ağrısından korunma ile ilgili kapsayıcı önlemler alınmalıdır. Kadınların kendi sağlıklarını korumayı öğrenebilmesi hedeflenerek halk eğitimleri düzenlenmelidir. Kadınlarda bel ağrısı sıklığı ve risk faktörlerini araştıran kesitsel araştırmaların say1s1 oldukça azdır. Daha doğru sonuçlara ulaşabilmek için bu çalışmaların sayısı arttırılmalıdır.

Etik Komite Onayı: Bu araştırma Dicle Üniversitesi Tıp Fakültesi Girişimsel Olmayan Klinik Araştırmalar Etik Kurulu tarafından onaylanmıştır (Tarih: 25.12.2015, karar no: 111).

Çıkar Çatışması: Yazarlar çıkar çatışması bildirmemişlerdir.

Yazar Katkıları: Fikir - CB; Denetleme - GS; Malzemeler - CB; Veri toplanması ve/veya işlemesiCB, GS; Analiz ve/veya yorum -GS, CB; Yazıyı yazan - CB.

Hakem Değerlendirmesi: Dış bağımsız.

\section{KAYNAKLAR}

1. Buchbinder R, Jolley D, Wyatt M. Population based intervention to change back pain beliefs and disability: Three part evaluation. BMJ. 2001;322:1516-20.

2. Woolf AD, Pfleger B. Burden of major musculoskeletal conditions. Bull World Health Organ. 2003;81:646-656.

3. Dündar PE, Özyurt BC, Özmen D. Manisa'da kırsal bir bölgede kadınlarda bel ağrısı sıklığı; ev işleri ve diğer faktörlerle ilişkisi. Ağrı Dergisi. 2006;18:51-64. 
4. Çınar Özdemir Ö, Sürmeli M, Özel A, Yavuz İE. Gebelerde fiziksel aktivite ve yaşam kalitesi arasındaki ilişki. Anadolu Kliniği Tıp Bilimleri Dergisi. 2017;22(2):95-102.

5. Yıldırım A. Kronik diskojenik bel ağrıları ve cerrahi dışı tedavi yöntemleri. Dicle Tıp Dergisi. 2016;43(1):181-191.

6. Kaapa EH, Frantsi K, Sarna S, Malnivaara A. Multidiscilinary group rehabilitation versus individual physiotherapy for chronic nonspecific low back pain: a randomized trial. Spine. 2006;31:371-376.

7. Esen ES, Toprak D. Bel Ağrısı Sıklığı ve İlişkili Faktörlerin Değerlendirilmesi. Ankara Med J, 2018;(4):460-469.

8. İlhan MN, Aksakal FN, Kaptan H, Ceyhan MN, Durukan E, İlhan F. Birinci Basamakta Yaşam Boyu Bel Ağrısı Sıklığı ve İlişkili Sosyal ve Mesleksel Risk Etmenleri. Gazi Tip Degisi 2011;21(3):107-10.

9. Yakut E, Düger T, Oksüz C, Et Al. Validation Of the Turkish Version of the Oswestry Disability Index for patients with low back pain. Spine. 2004;29:581-585.

10. Hagstromer M, Oja P, Sjostrom M. The international physical activity questionnaire (IPAQ): a study of concurrent and construct validity. Public Health Nutr. 2006;9:755-762.

11. Arıcı T, Uzuner B. Algoloji kliniğine başvuran hastaların tanı ve tedavilerinin değerlendirilmesi. Ortadoğu Tip Dergisi 2020;12(2):159-164.

12. Bansan D, Asrar M. M, Prevalence and impact of low back pain in a community-based population in Northern India. Pain Physician. 2020;23:389-398.

13. Bikbov M.M, Kazakbaeva G.M, Zainullin R.M. et al. Prevalence of and factors associated with low back pain, thoracic spine pain and neck pain in Bashkortostan, Russia: the Ural Eye and Medical Study. BMC Musculoskeletal Disorders. 2020;21:2-14.

14. Gilgil E, Kaçar C, Bütün B. Et al. Prevalence of low back pain in a developing urban setting. Spine. 2005;30(9):1093-1098.

15. Vindigni D, Walker BF, Jamison JR, Da Costa C, Parkinson L, Blunden S. Low back pain risk factors in a large rural Australian Aboriginal community. An opportunity for managing comorbidities? Chiropr Osteopat. 2005;13(21):412.

16. Yanıkkerem E. Obezitenin Kadın Sağlığına Etkileri. Kocaeli Üniversitesi Sağlık Bilimleri Dergisi. 2017;3(1):37-43
17. Şentürk AK. Malatya Eğitim ve Araştırma Hastanesi sağlık çalışanlarının fiziksel aktivite düzeyi, bel ağrısı ve yaşam kalitesi arasındaki ilişki. Malatya Üniversitesi, Tıp Fakültesi, Halk Sağl1ğ Anabilim Dalı, Yüksek Lisans Tezi. Malatya, Türkiye. 2020.

18. Yağc1 N, Cavlak U. Geriatrik bireylerde bel ağrısı riski. Cukurova Medical Journal. 2020;45 (2):421-427.

19. Bejia I, Younes M, Jamila HB. Prevalence and factors associated to low back pain among hospital staff. Joint Bone Spine. 2005;72(3):254-9.

20. Çil AA, Dereli E, Sert H. Kırklareli'nde çalışan hemşirelerde bel ağrısı ve bel ağrısı ile ilişkili faktörler. Acıbadem Üniversitesi Sağlık Bilimleri Dergisi. 2014;5(1):70-76.

21. Tavares P, Barret J. Prevalence of Low Back Pain, Pelvic Girdle Pain, and Combination Pain in a Postpartum Ontario Population. Women's Health. 2020;42(4):473-480.

22. Karabağ ÖO. Üniversite hastanesi çalışanlarında bel ağrısı prevalansı ve ilişkili risk faktörleri. Ege Üniversitesi Tip Fakültesi Anesteziyoloji ve Reanimasyon Anabilim Dalı, Tipta Uzmanlık Tezi. İzmir, Türkiye. 2016.

23. Levent A, Kamil ÇK, Elif CA. Profesyonel hastane çalışanlarında bel ağrısı prevalansı ve bel ağrısını etkileyen faktörler. Tıp Araştırmaları Dergisi. 2007;5(3):115-120.

24. Üstün Z. Bir Üniversite hastanesi hemşirelerinde bel ağrısı sıklığı fonksiyonel yetersizlik düzeyi ve ilişkili etmenler. Ankara Üniversitesi Tıp Fakültesi Halk Sağlığı Anabilim Dalı, Yüksek Lisans Tezi. Ankara, Türkiye. 2014.

25. Williams JS, Ng N, Peltzer K, et al. Risk factors and disability associated with low back pain in older adults in low and middle-income countries. Results from the WHO Study on Global AGEing and Adult Health (SAGE). PLoS One. 2015;10(6):e0127880. doi:10.1371/ journal.pone. 0127880

26. Šagát P, Bartík P, González PP, Tohănean DI. Impact of COVID-19 quarantine on low back pain intensity, prevalence and associated risk factors among adult citizens residing in Riyadh (Saudi Arabia): A cross-sectional study. Int. J. Environ Res Public Health. 2020;17(19):7302. doi:10.3390/ijerph17197302

27. Wáng YXJ, Wáng JQ, Káplár Z. Increased low back pain prevalence in females than in males afer menopause age: Evidences based on synthetic literature review. Quant Imaging Med Surg. 2016;6(2):199-206. 